\title{
Cómo se usa este libro
}

Las referencias cruzadas se indican con la palabra «véase» y el objeto de la referencia cruzada se escribe con mayúscula, por ej., en Factor de crecimiento nervioso (véase), o véase Inducción enzimática. Los números, letras griegas y las referentes a la configuración al principio de los nombres se ignoran en la ordenación alfabética; por ej., $\beta$-Galactosidasa aparecerá en la $\mathrm{G}$, L-Histidina en la letra $\mathrm{H}$; N-2-Hidroxietilpiperacina en la $\mathrm{H}$. El título de la entrada principal está escrito en negritas (se ha conservado el término inglés), seguido de los sinónimos en cursivas negritas. El resto del texto utiliza sólo otros dos tipos de letra, normal y cursiva.

Abreviaturas: (las abreviaturas bioquímicas estándar, por ej. ATP, NAD, etc., se encuentran como entradas en el orden alfabético adecuado).

abrev. abreviatura

$[\alpha] \quad$ rotación óptica específica

p.e. punto de ebullición

c concentración

${ }^{\circ} \mathrm{C} \quad$ grados Celsius

(d) con descomposición

$\rho$ densidad

IP punto isoeléctrico

M. $\quad$ molar

p.f. punto de fusión

$M_{\mathrm{r}} \quad$ masa molecular relativa

$n \quad$ índice de refracción

sin. sinónimo 
